Ann. Biol. anim. Bioch. Biophys., 1977, 17 (6), 1013-1019.

\title{
Temporal fluctuations of plasma LH and testosterone in Charolais bull calves during the first year of life
}

\author{
par A. LACROIX, Danielle-Hélène GARNIER, J. PELLETIER \\ with the technical assistance of A. CARATY and Odile MOULIN \\ Station de Physiologie de la Reproduction, I. N. R. A. \\ Nouzilly 37380 Monnaie, France.
}

\begin{abstract}
Summary. Plasma LH and testosterone have been measured by radioimmunoassay in samples collected weekly from 10 Charolais male calves from birth till one year of age. Plasma $\mathrm{LH}$ increased from the Ist to the 5 th week of age, then fluctuated widely from the 5 th to the 20 th week $(3-5 \mathrm{ng} / \mathrm{ml})$ and finally decreased to about $2 \mathrm{ng} / \mathrm{ml}$ and remained steady up to one year of age. Plasma testosterone increased very slowly from the lst to the 20 th week of age and then increased more rapidly with large fluctuations up to one year.

Thus an intense LH release between the Ist and the 5th month of life was not followed by a clear testosterone release suggesting that fesficular sensitivity to $\mathrm{LH}$ was not yet established. Conversely, after the sixth month of age discrete LH variations were able to induce large releases of testosterone into the blood. It is suggested that high pituitary activity during the first month of life is a signal for puberty.
\end{abstract}

Despite the number of recent studies devoted to plasma $\mathrm{LH}$ and testosterone in calves, a comprehensive view concerning the relationship between these hormones during the first year of age is still lacking. Thus plasma LH is said not to vary between the third and twelfth months of age (Odell, Hescox and Kiddy, 1970 ; Karg ef al., 1976) to increase between the first and seventh months (Mori et al., 1974) or to increase from seven months of age to adulthood (Gombe et al., 1973). Similarly although plasma testosterone was found to increase with age, this increase was said to be erratic (Rawlings, Hafs and Swanson, 1972) or multiphasic (Secchiari et al., 1976).

Some of these discrepancies could be due in part to a pulsatile pattern of relaese which has been described for LH both in adult (Katongole, Naftolin and Short, 1971) and young bulls (Gombe ef al., 1973 ; Thibier, 1975). They could arise also from insufficient blood samplings or number of animals studied.

This confusing sifuation in the bull contrasts with our knowledge in the sheep in which the prepubertal period is associated with a pulsatile pattern of $\mathrm{LH}$ followed by a decrease in the level after puberty, whereas testosterone increases linearly (Foster, 1974 ; Courot, de Reviers and Pelletier, 1975).

Thus, in an attempt to clarify the endocrine changes around puberty the concurrent patterns of plasma LH and testosterone were followed in Charolais calves from birth till one year of age. 


\section{Materials and methods.}

Ten Charolais calves born between January and April 1974 were used in this experiment. Body weights were recorded each month. Blood samples were collected by venepuncture from the jugular vein at $9.00 \mathrm{a}$.m. once a week from 1 to 52 weeks of age.

Plasmas were stored at $-14^{\circ} \mathrm{C}$ until the end of the collection period and all samples were assayed simulianeously for $\mathrm{LH}$ by radioimmunological methods (Pellefier, 1972 ; Lacroix, 1975) and for testosterone after extraction of 0.5 or $1 \mathrm{ml}$ of plasma with ethylacetate cyclohexane mixture (Iv/lv) (Garnier, Cotta and Terqui, in preparation). Antibody obtained by immunization of rabbits against testosterone 3-(0-Carboxy-) methyloxime coupled to bovine serum albumin cross-reacts with epitestosterone : 2 p. 100, $\Delta 4$-androstenedione: 4 p. 100, $5 \alpha$-androsian 3 B-17 B diol : 9 p. 100, dehydroepiandrosterone : 1.8 p. 100 and $5 \alpha$-dihydrostestosterone (DHT) 47 p. 100. Sensitivity read between 0.05 and $0.1 \mathrm{ng} / \mathrm{ml}$.

The results obtained with this technique fit closely with those obtained with a very specific gas-chromatography method (Attal, 1970). For example the correlation coefficient between methods was +0.85 for 236 assays of bovine plasma and the regression line $(y=0.8004 X-0.02)$ had a slope close to 1 . Comparisons with and without a chromatographic step on celite columns to isolcte testosterone from DHT showed this step to be unnecessary, indicating that DHT which cross-reacts strongly with the antibody used was at a negligible level compared to testosterone in bovine plasma.

Conversely, direct measurement of testosterone without any extraction led to higher values. Variation coefficients, were 4.37 p. 100 and 9.92 p. 100 for high and low values respectively (data from Dechesnes, 1976 : personnal communication).

Plasmas were assayed in iduplicates. LH results are expressed in $\mathrm{ng}$ LH Reichert $1072.2=2 \times \mathrm{NIH}-\mathrm{LH}-\mathrm{SI}$.

\section{Results.}

1. Growth. Body weight increased linearly with age from $47.5 \pm 2.1 \mathrm{~kg}$ at birth to $464 \pm 11 \mathrm{~kg}$ at one year of age $(r=+0.998 ; y=39.5+35.6 \times, P<0.001)$. Further growth was homogeneous between animals (variation coefficient 2.85 p. 100).

II. Plasma LH. LH was detectable in plasma at the first bleeding, four to eight days after birth, with a mean level of $1.29 \pm 0.30 \mathrm{ng} / \mathrm{ml}$. No correlation with body weight was evident. At one year of age mean plasma LH level was $2.19 \pm 0.10 \mathrm{ng} / \mathrm{ml}$. The mean LH level over the year varied from. 1.94 to $3.94 \mathrm{ng} / \mathrm{ml}$ between calves $(P<0.05)$. For the ten animals the over-all LH mean level was $2.62 \pm 0.17 \mathrm{ng} / \mathrm{ml}$.

The plasma LH pattern from birth till one year of age (fig. 1a) presented three phases:

- From birth to about five weeks of age, plasma LH increased regularly. During this period the mean plasma $\mathrm{LH}$ level was $2.26 \pm 0.23 \mathrm{ng} / \mathrm{ml}$.

- From five to about twenty weeks of age plasma LH showed large fluctuations 


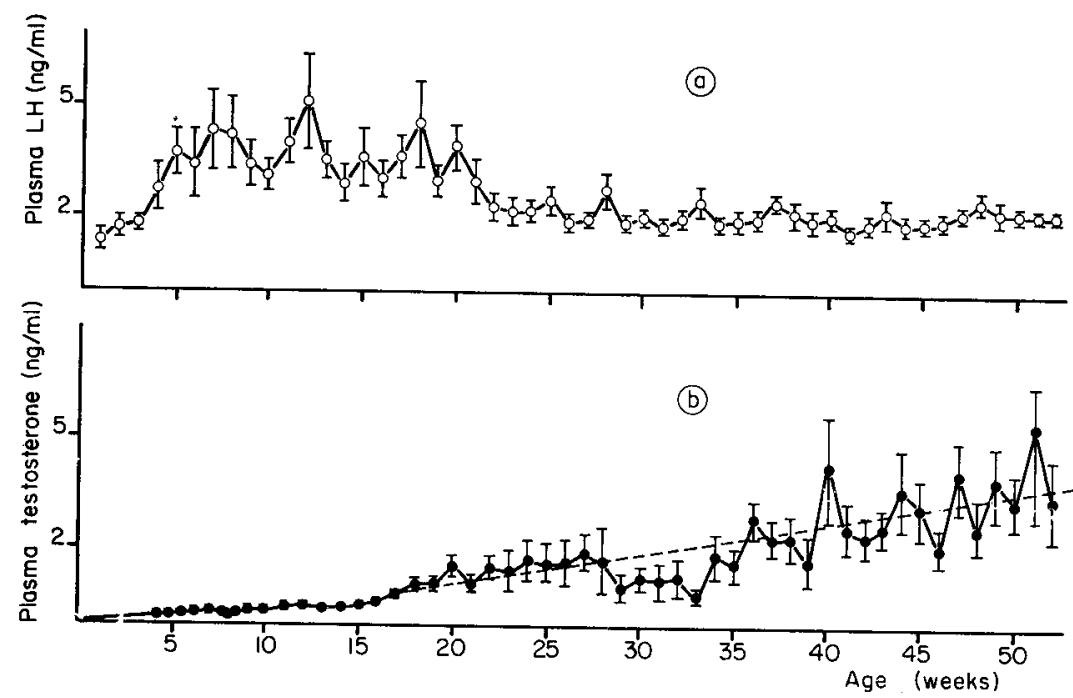

FIG. 1. - Plasma $L H$ (a) and festosterone (b) variations in ten Charolais bull calves from birth through one year of age (mean \pm SEM).

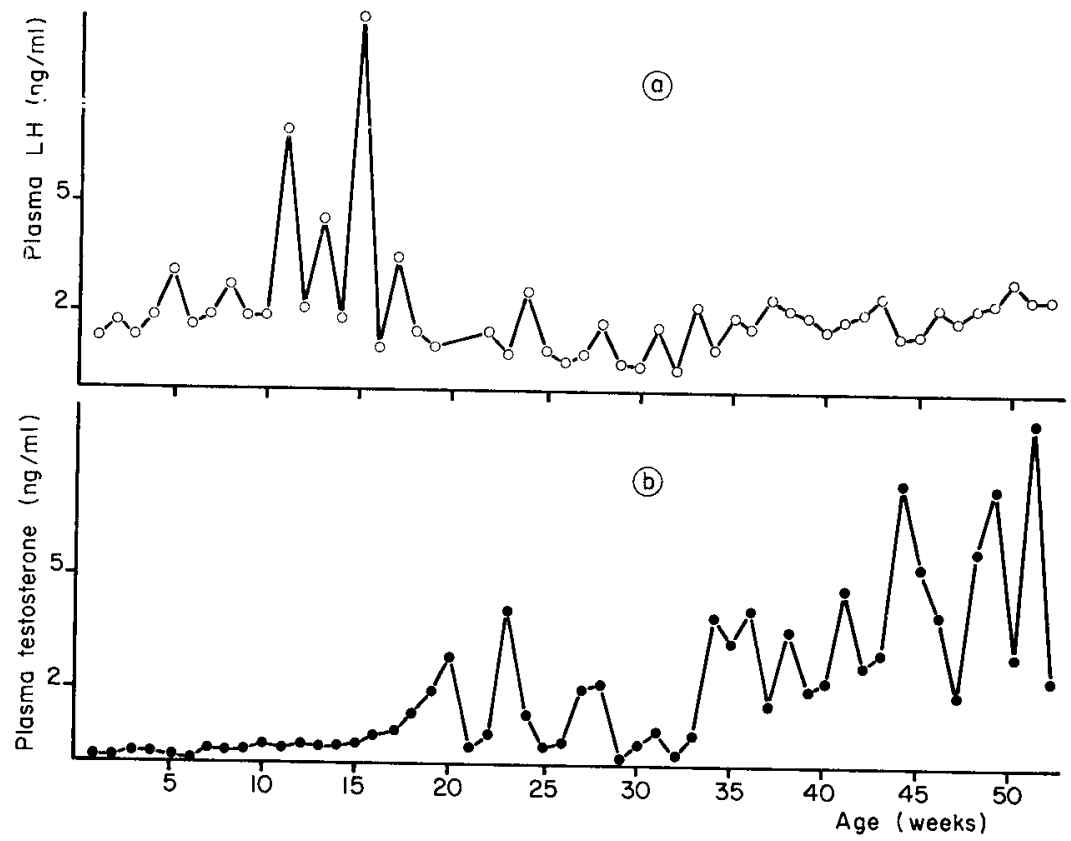

FIG. 2. - LH (a) and testosferone (b) patterns in one individual Charolais calf from birth through to one year of age. 
up to $20 \mathrm{ng} / \mathrm{ml}$ detectable in all individuals (fig. $2 a$ ) Mean plasma LH level during this phase was $3.72 \pm 0.20 \mathrm{ng} / \mathrm{ml}$.

- After the 20 th week of age, plasma LH gradually decreased with a progressive decline in the intensity of fluctuations, and the plasma level became stable around $2 \mathrm{ng} / \mathrm{ml}$. Mean plasma LH level during the period was $2.18 \pm 0.05 \mathrm{ng} / \mathrm{ml}$.

Analysis of variance showed that the mean LH levels during these three phases were highly significantly different $(P<0.001)$. Assuming that a value higher than 150 p. 100 of the over-all mean annual value (approximately $4 \mathrm{ng} / \mathrm{ml}$ ) corresponded to an LH peak in plasma, frequency of peaks varied significantly $(P<0.001)$ through the first year of age. The maximum number of peaks was found during the third and fourth months of age (fig. 3).

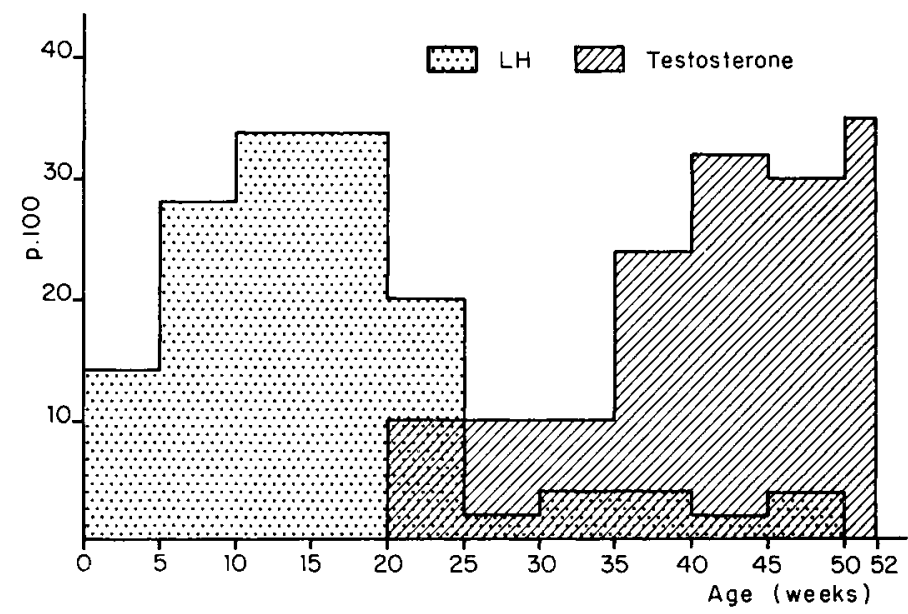

FIG. 3. - Frequency of $L H$ and testosterone peaks in plasma $(\geqslant 4 \mathrm{ng} / \mathrm{ml})$ in ten Charolais bull calves from birth through to one year of age.

III. Plasma testosterone. Plasma testosterone was very low at birth, being less than $0.1 \mathrm{ng} / \mathrm{ml}$, and at one year old had risen to $3.4 \pm 1.1 \mathrm{ng} / \mathrm{ml}$. The mean testosterone level over the year varied from $0.93 \pm 0.19$ to $2.49 \pm 0.48 \mathrm{ng} / \mathrm{ml}$ between calves $(P<0.02)$ with a 267 p. 100 difference between these extremities. For the ten animals the over-all LH mean level was $1.71 \pm 0.10 \mathrm{ng} / \mathrm{ml}$.

Three phases for LH could also be shown (fig. $1 b$ ).

- From 1 to 20 weeks of age plasma testosterone increased at first very slowly. Mean testosterone level was then $0.48 \pm 0.04 \mathrm{ng} / \mathrm{ml}$ and no major fluctuations were seen during this period. However, in some cases (fig. $2 b$ ) a sharper increase in plasma testosterone could be observed from the 15 th to the 20 th week of age.

- From 21 to 35 weeks of age the mean testosterone level was steady $(1.49 \pm$ $0.13 \mathrm{ng} / \mathrm{ml}$ ) but individual patterns fluctuated widely (fig. $2 \mathrm{~b}$ ).

- From the 36th week to one year of age, plasma testosterone levels gradually increased (mean value $=3.15 \pm 0.21 \mathrm{ng} / \mathrm{ml}$ ), as did the amplitude of fluctuations. 
Mean plasma testosterone levels during these three phases differed significantly $(P<0.001)$. The frequency of testosterone values higher than $4 \mathrm{ng} / \mathrm{ml}$, which was assumed to represent a peak, increased significantly with age up to one year of age $(P<0.001)$ (fig. 3).

IV. LH-festosterone interaction. An over-all significant negative correlation between plasma LH and testosterone throughout the year $(r=-0.46)$ was found. However a positive correlation $(r=+0.42)$ between birth and 20 weeks was observed; this correlation was nullified afterwards ( $r=-0.13)$.

Furthermore no correlation was observed between the mean annual individual levels of $\mathrm{LH}$ and testosterone $(r=0.03)$.

\section{Discussion.}

In Charolais calves, plasma LH firstly increases after birth, secondly varies widely from two to five months and then declines and remains steady up to one year of age. The main feature of this pattern is the second phase where large individual fluctuations occurred from week to weeks. This pattern has also been observed during the same prepubertal period in Friesian, Hereford, Limousin and Maine-Anjou breeds (Lacroix and Pelletier, unpublished data). Peak values are related to the presence of a pulsatile pattern of secretion, particularly intense in the two to five-month period (Lacroix and Pelletier, 1977). These results agree with high pituitary activity shown in sheep before puberty (Foster, 1974 ; Courot, de Reviers and Pelletier, 1975).

Afterwards the frequency of pulses decreases (see fig. 3) although they are presumably present during the whole lifespan (Katongole, Naftolin et Short 1971 ; Smith ef al., 1973 ; Thibier, 1975). These results differ markedly with those of Odell ef al. (1970) and Karg ef al. (1976) who showed no variations in plasma LH during the first year of life. Similarly, they differ from those of Mc Millan and Hafs (1968), Gombe et al. (1973), Swanson ef al. (1971) who indicated a major increase in plasma LH after the 6th month of life. An early increase in plasma LH was mentioned by Rawlings ef al. (1972) and Mori et al. (1974), although in those cases, monthly collection of blood minimized the phenomenon and the importance of the prepubertal period had not been previously pointed out.

There is general agreement concerning the pattern of plasma testosterone which increases roughly from birth to the first year of age with a faster increment after 6 months of age (Rawlings ef al., 1972 ; Secchiari ef al., 1976). However, neither a drop in plasma testosterone was observed between 11 and 12 months of age as suggested by Rawlings et al. (1972) nor a multiphasic pattern, as found by Secchiari ef al. (1976) in Friesan calves. Data from our Charolais calves indicate there are three steps in the increase of plasma testosterone, with the second and the third ones having large weekly variations. Another point of view would be to neglect the slight decrease observed between the 28th and 33rd week of age and to consider the testosterone increase roughly as linear (see fig. 1b). However, data from Secchiari ef al. (1976) and consideration of the number of peaks in plasma levels (fig 3) favours the first hypothesis. 
Finally the increase in testosterone level at one year of age cannot be considered as a high basal level but is the combination of pulses of testosterone and a basal level which remains in fact very low. The occasional absence of pulses could explain the decrease in plasma testosterone observed by Rawlings et al. (1972).

The main point of this study is however the correlation between plasma $\mathrm{LH}$ and testosterone. Firstly, one must consider that large LH variations before the 15 th week of age occurred in plasma without a response in testosterone which was confirmed by a monthly circahoral variations study of plasma $\mathrm{LH}$ and testosterone (Lacroix et Pelletier, 1977). Conversely, when plasma testosterone increased steeply from the 15-20th to the 25th week plasma LH decreased and major fluctuations disappeared. Thus, it seems highly probable that a large LH release during the first months of life is responsible for the increase in testosterone production which in turn moderates $\mathrm{LH}$ secretion. This period would correspond to initiation of testis sensitivity to $\mathrm{LH}$ and then the normal negative feed back mechanism would work. Secondly, ofter 6 months of age endocrine relationships found in the adult seem to be established with testosterone reaching values at one year of age as that observed at maturity.

During this period it seems that testicular sensitivity to $\mathrm{LH}$ is sufficiently high to ensure a large testosterone release in response to a discrete plasma LH change.

Although the role of FSH was not studied in this experiment, it seems at least that the pulsatile LH pattern in the calf as in the lamb is one of the earliest endocrine signals for puberty occurring around the ninth month of age in the Charolais breed without an evident effect of season.

Reçu en mars 1977.

Accepté en juin 1977.

Aknowledgements. - We would like to thank Drs C. Courte and L. E. Reichert for their gift of purified bovine LH and Y. de Fontaubert and his team for the management of animals.

Résumé. Les variations des taux de $\mathrm{LH}$ ef de testostérone plasmatiques ont été estimées par radioimmunologie à partir d'échantillons de sang collectés chaque semaine chez 10 veaux Charolais mâles depuis la naissance jusqu'à l'âge d'un an. En moyenne, la LH plasmatique augmente de 1 à 5 semaines d'âges, puis fluctue largement de la 5 e à la $20^{e}$ semaine $(3-5 \mathrm{ng} / \mathrm{ml})$ enfin décroît pour rester à un niveau relativement stable voisin de $2 \mathrm{ng} / \mathrm{ml}$ jusqu'à un an. La testostérone augmente très lentement entre 1 ef 20 semaines d'âge puis plus rapidement avec des grandes fluctuations de 20 semaines à un an.

Ainsi la secrétion intense de LH entre le premier et le $5^{\mathrm{e}}$ mois de vie ne s'accompagne que d'une réponse testiculaire réduite alors qu'après 6 mois d'âge la sensibilité testiculaire à la LH semble importante puisqu'on constate de grandes fluctuations de testostérone en réponse à des taux réduits de LH. Il est suggéré que la décharge de LH dans les premiers mois de vie correspond à un signal essentiel pour la puberté.

\section{References}

ATTAL J., 1970. Mesure des œestrogènes ef des androgènes testiculaires ef plasmatiques dans l'espèce ovine par les microméthodes de chromatographie en phase gazeuse. Influence de l'âge, de la saison et du cycle diurne. Thèse Doct. Sci., Paris, CNRS, $n^{0}$ AO, 4145, 143 p. 
COUROT M., DE REVIERS M. M., PELLETIER J., 1975. Variations in pituitary and blood LH during puberty in the male lamb. Relation to time of birth. Ann. Biol. anim. Bioch. Bioph., 15, 509-516.

FOSTER D. L., 1974. Regulation of gonadotropins during fetal and early post natal development in the sheep. Colloque INSERM, 32, 143-156, INSERM, ed.., Paris.

GARNIER D. H. COTTA Y., TERQUI M., Methodology assesment and testosterone dehydroepiandrosterone, $5 \propto$ dihydrotestosterone levels in the peripheral plasma of lambs and rams Ann. Biol. anim. Bioch. Biophys. (submitfed for publication).

GOMBE S., HALL W. C., McENTEE K., HANSEL W., PICKETT B. W., 1973. Regulation of blood levels of $\mathrm{LH}$ in bulls : influence of age, breed. sexual stimulation and temporal fluctuation. J. Reprod. Fert., 35, 493-503.

KATONGOLE C. B., NAFTOLIN F., SHORT R. U., 1971. Relationships between blood levels of LH and testosterone in bulls, and the effects of sexual stimulation. J. Endocr., 50, 547-466.

KARG H., GIMENEZ T., HARTL M., HOFFMANN B., SCHALLENBERGER E., SCHAMS D., 1976. Testosterone, luteinizing hormone $(\mathrm{LH})$ and follicle stimulating hormone (FSH) in pheripheral plasma bulls : levels from birth through puberty and short ferm variations. Zbl. Vet. Med. A., 23, 793-803.

LACROIX A., 1975. Dosage radioimmunologique de la LH plasmatique chez les bovins. Dipl. Et. Approf. Fac. Sc., Paris VI., 38 pp.

LACROIX A., PELLETIER J., 1977. Variations circahoraires de la LH plasmatique chez le veau mâle Relations LH-testostérone (Abstr.). J. Physiol., 73, 66A.

MCMILLAN K. L., HAFS H. D., 1968. Pituitary and hypothalamic endocrine changes associated with reproductive development of Holstein Bulls. J. anim. Sci., 27, 1614-1620.

MORI J., MASAKI J., WAKABAYASHI K., ENDO T., HOSODA T., 1974. Serum luteinizing hormone levels in cattle under various reproductive states. Theriogenology, 1, 131-136.

ODELL W. D., HESCOX M. A., KIDDY C. A., 1970. Studies of hypothalamic-pituitary-gonadal interrelations in prepubertal cattle, 371-385. In : BUTT W. R., CROOKE A. C., RYLE M., Gonadotrophins and ovarian development. E. and S. Livingstone, Edinburgh.

PELLETIER J., 1972. Dosages radioimmunologiques de la LH plasmatique ovine ef bovine, $237-255$. Coll. Techniques radioimmunologiques, I. N. S. E. R. M. Ed., Paris.

RAWLING N. C., HAFS H. D., SWANSON L. V., 1972. Testicular and blood plasma androgens in holstein bulls from birth through puberty. J. anim. Sci., 34, 435-440.

SECCHIARI P., MARTORANA F., PELLEGRINI S., LUISI M., 1976. Variation of plasma testosterone in developing Friesian bulls. J. anim. Sci., 42, 405-409.

SMITH O. W., MONGKONPUNYA K., HAFS H. D., CONVEY E. M., OXENDER W. D., 1973. Blood serum testosterone after sexual preparation or ejaculation or after injections of $\mathrm{LH}$ or prolactin in bulls. J. onim. Sci., 37, 979-984.

SWANSON L. V., WETTEMANN R. P., RAWLINGS N. C., HAFS H. D., MAGEE W. T., 1971. Pubertal relationships of some endocrine and reproductive criteria in Hereford bulls. J. anim. Sci., 33, 823-828.

THIBIER M., 1975. Variations circadiennes de la LH plasmatique chezle jeune taurillon. Ann. Endocr., Paris, 36, 205-210. 